\title{
Production and quality of chickpea seeds in different sowing and harvest periods ${ }^{1}$
}

\author{
Ramon Ivo Soares Avelar²*, Cândido Alves da $\operatorname{Costa}^{2}$, Delacyr da Silva Brandão \\ Júnior $^{2}$, Humberto Alencar Paraíso ${ }^{2}$, Warley Marcos Nascimento ${ }^{3}$
}

\begin{abstract}
The objective of this study was to evaluate the production, and the physical and physiological quality of 'BRS Aleppo' chickpea seeds in the city of Montes Claros, Minas Gerais State, and their ideal harvest point. A randomized complete block design was used, in a 3x5 factorial arrangement, with three sowing periods (May 12th, June 23rd and July 22nd 2015) and five harvest seasons (100, 107, 114, 121 and 128 days after sowing) with seven replications. The following productive parameters were determined: number of seeds, number of empty pods, production and yield. For seed quality evaluations, the completely randomized design was used. The following evaluations were done: seed moisture content, dry matter, biometry, 1,000 -seed weight and germination. For the harvest season factor, data were submitted to analysis of variance and comparisons average by Tukey's test $(\mathrm{p}<0.05)$. The regression analysis was performed and coefficients were tested with the t-test. Seed production was higher when sowing was done in May and when the harvest was performed close to 114 days after sowing, with a yield reaching 5.31 ton $/ \mathrm{ha}^{-1}$ and $10.7 \%$ seed moisture content. If sowing is delayed, there is a risk of rainfall during the harvest season, and seed quality is compromised.
\end{abstract}

Index terms: Cicer arietinum, BRS Aleppo, physiological maturity, germination, biometrics.

\section{Produção e qualidade de sementes de grão-de-bico em diferentes épocas de semeadura e colheita}

\begin{abstract}
RESUMO - Objetivou-se no estudo avaliar a produção, qualidade física e fisiológica de sementes de grão-de-bico 'BRS Aleppo' no município de Montes Claros-MG e determinar o ponto ideal de colheita. Utilizou-se o delineamento em blocos casualizados, no esquema fatorial 3x5, sendo três épocas de semeadura (12/Maio, 23/Junho e 22/Julho) e cinco épocas de colheita (100, 107, 114, 121 e 128 dias após a semeadura) e sete repetições. Foram avaliados os parâmetros produtivos: número de sementes, número de vagens vazias, produção e produtividade. Para as avaliações da qualidade das sementes, adotou-se o delineamento experimental inteiramente casualizado. Foram avaliados o grau de umidade, massa seca, biometria, peso de mil sementes e germinação. Para o fator época de semeadura, os dados foram submetidos à análise de variância e as médias comparadas pelo teste Tukey $(\mathrm{p}<0,05)$. Foi realizada análise de regressão e os coeficientes testados pelo teste t. A melhor época de semeadura para produção e qualidade de sementes de grão-de-bico é o mês de maio e colheita próximo a 114 dias após a semeadura, com produtividade de 5,31 tha ${ }^{-1}$ e sementes com umidade de 10,7\%. À medida que ocorre atraso no plantio, há risco de chuvas no período de colheita e comprometimento da qualidade das sementes.
\end{abstract}

Termos para indexação: Cicer arietinum, BRS Aleppo, maturidade fisiológica, germinação, biometria.

\section{Introduction}

The cultivation of chickpeas was little explored in Brazil and, until 2010, there was no productive area in the country.

${ }^{1}$ Submitted on 11/16/2017. Accepted for publication on 04/03/2018. ${ }^{2}$ Instituto de Ciências Agrárias (ICA) - UFMG - Campus Regional de Montes Claros, 39404-547 - Montes Claros, MG, Brasil.
The importation of seeds is one of the factors that increase the production cost and therefore cultivation may become unfeasible.

In terms of genetic improvement, efforts have been made to offer cultivars that are more productive, resistant to

${ }^{3}$ EMBRAPA Hortaliças, Rodovia BR-060, Km 09 (Brasília/Anápolis), Caixa Postal: 218, 70275-970 - Brasília, DF, Brasil.

*Corresponding author <ramonavelar.agronomia@yahoo.com> 
diseases and tolerant to climatic variations. In 2014, cultivar BRS Aleppo was launched by Embrapa Hortaliças; it is more tolerant to Fusarium spp. and more productive than the ones available in the market (Nascimento et al., 2014). In the central-western region of Brazil, the yield of this cultivar exceeds 3,000 kg. ha-1 (Artiga et al., 2015). Moreover, it has desirable characteristics for the canning industry and for the commercialization of dry grains (Nascimento et al., 2016). From 2015, the cultivation began to be widespread and foreign trade became an attractive for producers.

The success in reaching the maximum yield of the chickpea production, as in other crops, depends on management, use of supplies in quantity and quality, and especially on the quality of seeds. Seed production requires the same care as grain production, with some aspects to be considered: choosing the cultivation and management area, which involves the practice of roguing and controlled irrigations (Nascimento et al., 2016).

Chickpea cultivation is more indicated in well-drained and deep soils, with a silty-clayey texture, rich in nutrients and organic matter, and with a $\mathrm{pH}$ between 6.5 and 7.0. It is not very demanding in terms of water and it develops well in regions with a low to medium rainfall and moderate cold. Irrigation frequency is weekly and up to $10 \mathrm{~mm}$, in order to avoid the incidence of diseases. Irrigations should not exceed $400 \mathrm{~mm}$ during the whole cycle (Nascimento et al., 2016; Silva, 1998). In tropical regions, it can be cultivated in winter and in temperate regions in spring/summer (Rao et al., 2010). In Brazil, it develops well in cerrado regions, during dry winter periods, with its planting performed in summer/fall. Therefore, it needs complementary irrigations.

Excessive rainfall after planting or during the breeding season can cause problems in emergence, fertilization, as well as stimulating plants to shed flowers for an indeterminate period and not to enter the maturation process. High temperatures reduce the period of vegetative growth and cause flower abortion, causing a significant reduction in production (Nascimento et al., 2016).

The maximum and minimum favorable temperatures to a good development for most chickpea cultivars are $25{ }^{\circ} \mathrm{C}$ to $30{ }^{\circ} \mathrm{C}$ and $10{ }^{\circ} \mathrm{C}$ to $15{ }^{\circ} \mathrm{C}$, respectively. The optimum germination temperature lies between $20^{\circ} \mathrm{C}$ and $30{ }^{\circ} \mathrm{C}$, and seedling emergence occurs under these conditions, five to six days after sowing (Nascimento et al., 2016).

Right after the development of pods and filling, the yellowing of plants occurs and the leaves move to the senescence stage. Irrigations are suspended when $90 \%$ of the stems and pods lose their green color, becoming golden yellow. This occurs close to 98 days after planting, according to the recommendations of Nascimento et al. (2016), Marouelli et al. (2010), Nascimento et al. (1998) and Silva (1998).

Harvesting is carried out in winter/spring, during the period when there is the slightest possibility of rainfall (Nascimento et al., 2014; Pessoa, 1998). Seeds must have proper moisture, between 13 and 15\%, in order to avoid mechanical damages (Nascimento et al., 2016).

There is little information about the best growing and harvesting periods, aiming at the maximum quality of chickpea seeds. Seed vigor and viability losses begin on the production field and, when not controlled, reflect on their performance and storage. The objective of this study was to evaluate the physical and physiological quality of chickpea seeds from the BRS Aleppo cultivar, cultivated under irrigated system, in different sowing and harvesting periods, in the municipality of Montes Claros, Minas Gerais state, and to determine the ideal harvesting point.

\section{Material and Methods}

The experiment was conducted in the municipality of Montes Claros - Minas Gerais state, Lat. 160 $40^{\prime} 56^{\prime \prime}$, longitude $43^{\circ} 50^{\prime} 24$ 'W, with the climatic Köppen classification Aw, altitude $646 \mathrm{~m}$, from May to December 2015. The daily climatic data regarding the duration of the experiments were obtained by the 83437 meteorological station of INMET (2015).

In the field experiment, the design was in randomized blocks, with a $3 \times 5$ factorial arrangement and three sowing dates (May 12th, June 23rd, and July 22nd), five harvesting periods (100, 107, 114, 121 and 128 days after sowing) and seven replications. Each plot was composed of a 5-meter bed with 4 rows spaced $0.50 \mathrm{~m}$ and 10 seeds per linear meter, resulting in a planting density of 200,000 plants. ha ${ }^{-1}$.

The chemical and physical characteristics of the soil from the experimental area were the following: $\mathrm{pH}$ in water 6.8; P-Mehlich (mg.dm ${ }^{-3}$ ) 3.89; remanescent P (mg. $\left.\mathrm{L}^{-1}\right)$ 31.74; available K (mg.dm $\left.{ }^{-3}\right) 249 ; \mathrm{Ca}\left(\mathrm{cmolc}^{\left.-\mathrm{dm}^{-3}\right)} 6.40 ; \mathrm{Mg}\right.$ $\left(\mathrm{cmolc} . \mathrm{dm}^{-3}\right)$ 1.60; $\mathrm{Al}\left(\mathrm{cmolc} . \mathrm{dm}^{-3}\right)$ 0.0; $\mathrm{H}+\mathrm{Al}\left(\mathrm{cmolc} . \mathrm{dm}^{-3}\right)$ 1.42; SB (cmolc. $\left.\mathrm{dm}^{-3}\right)$ 8.64; $\mathrm{t}\left(\mathrm{cmolc}^{\left.-\mathrm{dm}^{-3}\right)} 8.64 ; \mathrm{m} \mathrm{( \% )} \mathrm{0.0;} \mathrm{T}\right.$ (cmolc. $\mathrm{dm}^{-3}$ ) 10.06; V (\%) 86; organic matter (dag. $\left.\mathrm{kg}^{-1}\right)$ 3.39; organic carbon (dag.kg-1 1.96 ; coarse sand (dag. $\left.\mathrm{kg}^{-1}\right)$ 12.00; fine sand (dag. $\left.\mathrm{kg}^{-1}\right)$ 20.00; silt (dag. $\mathrm{kg}^{-1}$ ) 40.00; clay (dag. $\mathrm{kg}^{-1}$ ) 28.00; textural classification: medium.

Fertilization was based on the recommendation of Pessoa (1998), according to the soil analysis results. In order to raise phosphorus levels, $60 \mathrm{~g}$ of simple superphosphate were used per linear meter. The $\mathrm{pH}$ was high (6.8). It was decided to use the $\mathrm{N}$ source (Ammonium Sulphate) in cover, in the amount of $60 \mathrm{~kg} \cdot \mathrm{ha}^{-1}, 40$ days after sowing (DAS), before the beginning of flowering. 
The used chickpea cultivar was BRS Aleppo. Seeds were previously treated (based on the recommendations for bean culture) with a fungicide from the Phenylurea group and with a systemic, contact and ingestion insecticide, from the neonicotinoid and oxcarb methylcarbamate groups.

Manual weeding was performed weekly, until the establishment of the weed control culture. After the beginning of flowering, three preventive applications of a systemic insecticide (group: neocotinoid and pyrethroid) were performed in each growing season, with a 15-day interval after the beginning of flowering, and also a contact one (pyrethroid group; Deltamethrin-based [2.5\%]), for caterpillar control. The roguing practice was performed on plants with symptoms of Fusarium spp., after morphological identification.

Irrigations were done by micro spraying, according to the recommendation by Silva (1998): a $20 \mathrm{~mm}$ water layer, after sowing, considering the dry soil and, until the emergence of seedlings, $5 \mathrm{~mm}$ every two days. After the emergence of seedlings, there was only one irrigation per week in amounts of $15 \mathrm{~mm}$, between 0 and 10 days after emergence (DAE). During plant development, $25 \mathrm{~mm}$ between 16 and 42 days, $35 \mathrm{~mm}$ between 43 and 84 days were applied. The paralysis of irrigations was based on the recommendations by Marouelli et al. (2010) and Nascimento et al. (1998), at 100 DAS, verified by the color change of plants at the senescence stage.

Pods were harvested manually in the experimental field and taken to the Laboratório de Análise de Sementes (LASICA/UFMG) for separation, production quantification and seed quality analysis. Eight plants per plot, from the central rows, were evaluated at each harvesting time and season. As for seed production, the following characteristics were evaluated:

Percentage of empty pods: the average number of pods that did not form seeds and the number of pods broached with seed damages was quantified, and data were expressed as $\%$.

Percentage of pods with one and two seeds: four plants per replication were used to quantify the number of pods with one and two seeds, expressed as percentage.

Number of seeds per plant: it was obtained from the sum of the number of pods with one and two seeds, on an average, from the four evaluated plants per replication.

Production: four plants per replication were used to quantify production, expressed as g/plant.

Plant density during the harvest: the number of productive plants per linear meter of the central rows was calculated, and the plant density during the harvest was determined as the number of productive plants per hectare (n. plants $/ \mathrm{ha}^{-1}$ ).

Yield: from the plant density during the harvest and the production data, it was possible to estimate the yield as $\mathrm{t} / \mathrm{ha}^{-1}$.

In order to evaluate the quality of chickpea seeds, the experimental design was a completely randomized one, in the $3 \times 5$ factorial arrangement (seeds from three sowing dates - May 12th, June 23rd, and July 22nd) and five harvesting seasons $(100,107,114,121$ and 128 days after sowing - DAS).

The quality of seeds was evaluated by the following tests:

Moisture degree: determined by the method with a forced air circulation greenhouse, regulated at $105 \pm 3{ }^{\circ} \mathrm{C}$ for 24 hours, according to the methodology prescribed in the Rules for Seed Testing - RST (Brasil, 2009), with four replications of 25 seeds, and the results expressed as percentage.

Seed dry matter: the seeds used to determine the moisture degree were weighed after drying, and the weight of the seed dry matter was determined as grams.

1,000-seed weight: eight replications of 100 seeds were used; they were weighed on a precision analytical scale $(0.001 \mathrm{~g})$, following the criteria established in the RST (Brasil, 2009), and the results were expressed as grams.

Seed and pod biometry: four replications of 25 seeds from 100 pods were used, which were later used in the germination test. The length, width and thickness of pods (Figure 1) and seeds (Figure 2) were measured using a digital caliper $(0.01 \mathrm{~mm}$ accuracy) and the results were expressed as $\mathrm{mm} /$ pod and $\mathrm{mm} / \mathrm{seed}$.

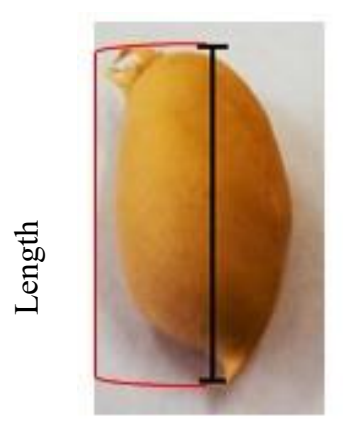

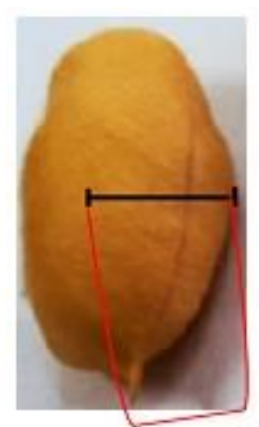

Thickness

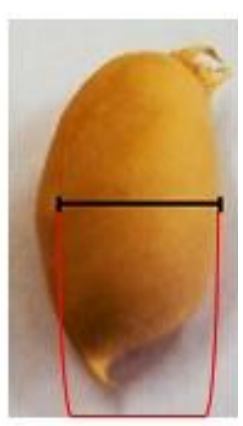

Width
Figure 1. Measurements of the length, width and thickness of chickpea pods.
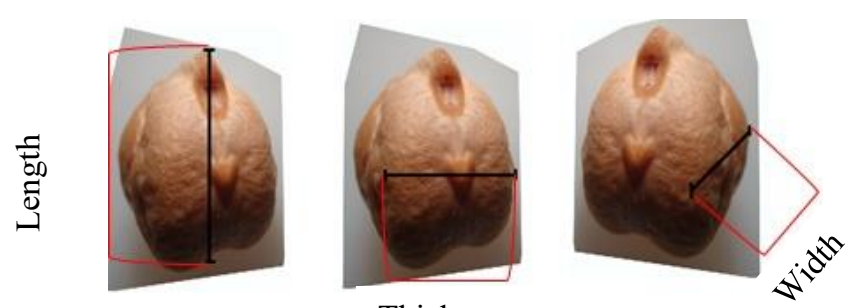

Thickness

Figure 2. Measurements of the length, width and thickness of chickpea seeds. 
Germination test: in the germination test, the used substrate was paper towel, in the roller system, moistened with deionized water at a the volume that was equivalent to 2.5 times the dry paper weight. The rolls were stored in plastic bags and kept in a germinator (Fanem type, model $347-\mathrm{G})$ previously regulated at $25^{\circ} \mathrm{C}$ and constant light. The evaluated parameters were: first and second abnormal and non-germinated normal seedling counts, five and eight days after the test was set up, expressed as \%. Seed germination was determined in the first count of normal seedlings, five days after the germination test was set up. In this phase, the maximum percentage of seedlings was obtained.

Germination rate index (GRI): for the determination of the GRI, daily counts of the number of normal seedlings were performed, until the last one. At the end of the test, the germination rate index was calculated, using the formula proposed by Maguire (1962).

Seedling length: at the end of the germination test, the average lengths of the shoot and primary root of normal seedlings were determined using a digital caliper (accuracy of $0.01 \mathrm{~mm}$ ), and the results were expressed as $\mathrm{mm} /$ seedling.

Seedling dry matter: the normal seedlings obtained in the germination test, were placed in paper bags after the measurements and were submitted to drying in a forced air circulation oven, at constant $65{ }^{\circ} \mathrm{C}$, for 72 hours. After this period, the samples were placed in desiccators and weighed on a precision analytical scale $(0.001 \mathrm{~g})$, with the results expressed as $\mathrm{g} /$ seedling.

The discrete quantitative data deriving from counting and expressed as percentage were initially transformed into and $\operatorname{sen}^{-1}$, respectively. For the sowing period factor, data were submitted to analysis of variance, and the means were compared by Tukey's test at $5 \%$ probability. A regression analysis was performed, where regression coefficients were tested by the $t$ test. The statistical analyses were performed with the R software (v. 3.2.2).

\section{Results and Discussion}

The climatic conditions during the crop cycle, the minimum, medium and maximum temperatures, the monthly relative air humidity and rainfall were represented in Figure 3. The maximum and minimum temperatures during the experimental period ranged from $16.1{ }^{\circ} \mathrm{C}$ to $22.9^{\circ} \mathrm{C}$, and from $28.8^{\circ} \mathrm{C}$ to $35.5^{\circ} \mathrm{C}$, respectively. According to Nascimento et al. (2016), temperatures above $30{ }^{\circ} \mathrm{C}$ are considered high for chickpea cultivation. During the whole period, the maximum temperatures were close to $30{ }^{\circ} \mathrm{C}$, being high from August. The highest temperatures occurred at the reproductive stage of the June 23rd sowing, and at the vegetative and reproductive stage of the July 22nd sowing; this is one of the factors that resulted in a low seed production.

There was an interaction effect between the sowing and harvesting seasons for the evaluated characteristics, except for pod width and thickness. The control of caterpillars, in general, was efficient. Damages caused to seeds and pods were, on an average, $2.5 \%$ in the May and July sowing. On the other hand, in the June sowing, damages reached $8.1 \%$, which shows a considerable decrease in production. Despite reaching the economic damage level, the number of empty pods did not differ significantly.

The percentage of pods with one and two seeds differed only in the sowing from June to the end of the cycle (128 DAS), according to Table 1. It was lower at that stage, $34 \%$ pods with one seed, compared to the other growing seasons, and it obtained the highest amount of pods with two seeds $(66 \%)$. The percentage of pods with one seed was, on an average, $85 \%$ in the May 12 th sowing and $83 \%$ in the July $23 \mathrm{rd}$ sowing. There was also a reduction in the number of seeds per plant at 128 DAS, as observed in Table 1. The highest number of seeds per plant was at 114 DAS of the May 12th sowing, with 147 seeds. The sowing period contributed to reduce the number of seeds; the June 23rd and July 22nd sowing had, on an average, 71 and 66 seeds per plant, respectively.

The incidence of diseases caused by soil fungi occurred during the period when temperatures were high (August/ September), which also contributed to the occurrence of unproductive plants and a significant reduction in plant density in the harvest of the June and July sowing. The planting density was 200,000 plants $/ \mathrm{ha}^{-1}$; on the other hand, it

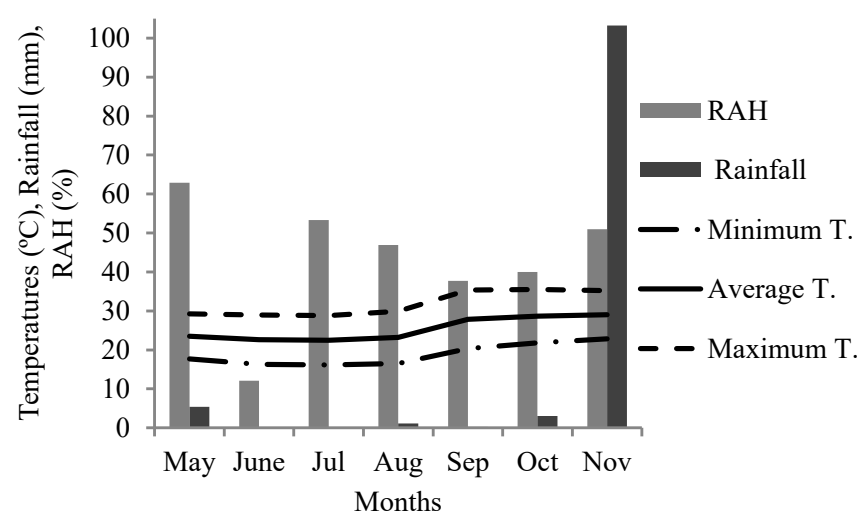

Figure 3. Meteorological data during the period MayNovember 2015. Average monthly temperatures: minimum, maximum and average, relative air humidity and rainfall. Weather station 83437 in Montes Claros - Minas Gerais state. INMET (2015). 
Table 1. Percentage of pods with one and two seeds and number of chickpea seeds per plant, in different periods of sowing and harvesting.

\begin{tabular}{|c|c|c|c|c|c|}
\hline \multirow{2}{*}{$\begin{array}{c}\text { Days after } \\
\text { sowing }\end{array}$} & \multicolumn{3}{|c|}{ Sowing periods } & \multirow{2}{*}{\multicolumn{2}{|c|}{ Adjusted equations }} \\
\hline & May 12 th & June 23rd & July 22nd & & \\
\hline & \multicolumn{3}{|c|}{----- \% pods with 1 seed ------ } & \multicolumn{2}{|l|}{ May 12th } \\
\hline 100 & $88(1.27) \mathrm{a}$ & $86(1.19) \mathrm{a}$ & $86(1.19) \mathrm{a}$ & $\overline{\mathrm{y}}=85^{\mathrm{ns}}$ & \\
\hline 107 & $79(1.11) \mathrm{a}$ & $73(1.03) \mathrm{a}$ & $86(1.19) \mathrm{a}$ & June 23rd & \\
\hline 114 & $86(1.19) \mathrm{a}$ & $83(1.15) \mathrm{a}$ & $77(1.08) \mathrm{a}$ & $\hat{\mathrm{Y}}=80.89+1.23 \mathrm{x}-0.099 * * \mathrm{x}^{2}$ & $\mathrm{R}^{2}=0.87$ \\
\hline 121 & $83(1.15) \mathrm{a}$ & $69(0.98) \mathrm{a}$ & $81(1.13) \mathrm{a}$ & July 22nd & \\
\hline 128 & $87(1.21) \mathrm{a}$ & $34(0.62) \mathrm{b}$ & $83(1.15) \mathrm{a}$ & $\overline{\mathrm{y}}=83^{\mathrm{ns}}$ & \\
\hline $\mathrm{CV}$ & \multicolumn{3}{|c|}{$9.47 \%$} & & \\
\hline \multirow{2}{*}{$\begin{array}{c}\text { Days after } \\
\text { sowing }\end{array}$} & \multicolumn{3}{|c|}{ Sowing periods } & \multirow{2}{*}{\multicolumn{2}{|c|}{ Adjusted equations }} \\
\hline & May 12th & June 23rd & July 22nd & & \\
\hline & \multicolumn{3}{|c|}{----- \% pods with 2 seeds ------ } & May 12th & \\
\hline 100 & $12(0.31)$ a & $14(0.38) \mathrm{a}$ & $14(0.38) \mathrm{a}$ & $\overline{\mathrm{y}}=15^{\mathrm{ns}}$ & \\
\hline 107 & $21(0.46) \mathrm{a}$ & $27(0.55) \mathrm{a}$ & $14(0.38) \mathrm{a}$ & $\underline{\text { June } 23 \mathrm{rd}}$ & \\
\hline 114 & $14(0.37) \mathrm{a}$ & $17(0.42) \mathrm{a}$ & $23(0.49) \mathrm{a}$ & $\hat{\mathrm{Y}}=19.11+1.23-0.099 * * \mathrm{x}^{2}$ & $\mathrm{R}^{2}=0.87$ \\
\hline 121 & $17(0.42) \mathrm{a}$ & $31(0.59) \mathrm{a}$ & $19(0.44) \mathrm{a}$ & July 22nd & \\
\hline 128 & $13(0.95) \mathrm{b}$ & $66(0.42) \mathrm{a}$ & $17(0.36) \mathrm{b}$ & $\overline{\mathrm{y}}=17^{\mathrm{ns}}$ & \\
\hline $\mathrm{CV}$ & & $22.72 \%$ & & & \\
\hline \multirow{3}{*}{$\begin{array}{c}\text { Days after } \\
\text { sowing }\end{array}$} & \multicolumn{3}{|c|}{ Sowing periods } & \multirow{2}{*}{\multicolumn{2}{|c|}{ Adjusted equations }} \\
\hline & May 12th & June 23rd & July 22nd & & \\
\hline & \multicolumn{3}{|c|}{------ N. of seeds per plant ------- } & \multicolumn{2}{|l|}{ May 12th } \\
\hline 100 & $77(8.65) \mathrm{a}$ & $76(8.73) \mathrm{a}$ & $48(6.9) b$ & $\hat{\mathrm{Y}}=56.27+7.74 * * \mathrm{x}-0.22 * * \mathrm{x}^{2}$ & $\mathrm{R}^{2}=0.44$ \\
\hline 107 & $52(7.14) \mathrm{a}$ & $66(8.10) \mathrm{a}$ & $58(7.61) \mathrm{a}$ & $\underline{\text { June } 23 \mathrm{rd}}$ & \\
\hline 114 & $147(12.10) \mathrm{a}$ & $43(6.50) \mathrm{c}$ & $69(8.30) \mathrm{b}$ & $\overline{\mathrm{y}}=71^{\mathrm{ns}}$ & \\
\hline 121 & $135(11.55) \mathrm{a}$ & $131(11.41) \mathrm{a}$ & $85(9.20) b$ & July 22nd & \\
\hline 128 & $88(9.41) \mathrm{a}$ & $41(6.36) b$ & $72(8.51) \mathrm{a}$ & $\overline{\mathrm{y}}=66^{\mathrm{ns}}$ & \\
\hline $\mathrm{CV}$ & & $9.62 \%$ & & & \\
\hline
\end{tabular}

Averages followed by the same letter on the lines do not differ from each other by Tukey's test $(p<0.05)$.

Data transformed by arc sine. $* * ; *$ Significant at 1 and $5 \%$, respectively, by the t-test.

was 9 plants $/ \mathrm{m}^{-1}$ in the harvest of the May 12th sowing (170 thousand plants $\left./ \mathrm{ha}^{-1}\right), 6$ plants $/ \mathrm{m}^{-1}$ in the June 23rd sowing (122 thousand plants $/ \mathrm{ha}^{-1}$ ) and, in the July 22 nd sowing, 5 plants $/ \mathrm{m}^{-1}$ (102 thousand plants $\left./ \mathrm{ha}^{-1}\right)$, according to Table 2 .

Generally speaking, seed production was higher in the May 12th sowing (Table 2), compared to the other periods. Close to 107 DAS there was the largest one, with $57.67 \mathrm{~g} /$ plant and a yield of $9.80 \mathrm{t} / \mathrm{ha}^{-1}$. Despite presenting a higher production, seed moisture was at $48.39 \%$, which is unsuitable for storage. At 114 DAS of the same period, moisture decreased to $10.70 \%$, production decreased to $31.26 \mathrm{~g} / \mathrm{plant}$ and yield to $5.31 \mathrm{t} / \mathrm{ha}^{-1}$. Hoskem et al. (2017) obtained yields above $3.0 \mathrm{t} / \mathrm{ha}^{-1}$ with the Cícero cultivar, but with a poor physiological and sanitary quality.

The moisture content of seeds reduced throughout the harvest season in the different sowing periods (Table 3 ). In the May 12th sowing, there was a linear reduction. At 100 DAS, when irrigation was suspended, the moisture content was higher compared to the other seasons, $60.78 \%$ on an average, followed by the July sowing with $30.08 \%$, and the lowest moisture at this stage was observed in the June 23rd sowing, with $17.39 \%$. At $114 \mathrm{DAS}$, in the three sowing periods, adequate values were found for storage, $9.35 \%$ on an average. The 1,000-seed weight at this stage was $175.03 \mathrm{~g}$ for the May 12 th sowing, and $195.48 \mathrm{~g}$ for the July $22 \mathrm{nd}$ sowing. The June 23 rd sowing was not different in terms of 1,000-seed weight in the harvest seasons, with $204.90 \mathrm{~g}$ on an average. This is due to the fact that seeds from this sowing period suffered a smaller amount of changes in terms of moisture content.

According to Marcos-Filho (2005), the ideal moisture is close to $12 \%$, for most species, which contributes to their greater longevity. The reduction in the moisture level in the May 12th sowing was linear and moisture at the end of the cycle, 128 DAS, was $5.97 \%$. In this situation, seeds with a very low moisture content can be damaged by imbibition. Moreover, dehiscence of some pods occurred, which may 
Table 2. Production, seed yield and density of chickpea plants in different periods of sowing and harvesting.

\begin{tabular}{|c|c|c|c|c|c|}
\hline \multirow{2}{*}{$\begin{array}{l}\text { Days after } \\
\text { sowing }\end{array}$} & \multicolumn{3}{|c|}{ Sowing periods } & \multirow{2}{*}{\multicolumn{2}{|c|}{ Adjusted equations }} \\
\hline & May 12th & June 23 rd & July 22nd & & \\
\hline & \multicolumn{3}{|c|}{-- Production of seeds per plant $(\mathrm{g})--$} & \multicolumn{2}{|c|}{ May 12th } \\
\hline 100 & $31.33 \mathrm{a}$ & $16.28 \mathrm{~b}$ & $7.04 \mathrm{~b}$ & \multicolumn{2}{|c|}{$\mathrm{Y}=37.64+0.97 \mathrm{x}-0.061 * * \mathrm{x}^{2} \quad \mathrm{R}^{2}=0.53$} \\
\hline 107 & $57.67 \mathrm{a}$ & $15.53 \mathrm{~b}$ & $14.67 \mathrm{~b}$ & \multicolumn{2}{|c|}{ June $23 \mathrm{rd}$} \\
\hline 114 & $31.26 \mathrm{a}$ & $13.03 \mathrm{~b}$ & $14.16 \mathrm{~b}$ & \multicolumn{2}{|l|}{$\overline{\bar{y}}=12.32^{\text {ns }}$} \\
\hline 121 & $29.38 \mathrm{a}$ & $18.84 \mathrm{a}$ & $21.51 \mathrm{a}$ & \multicolumn{2}{|l|}{ July 22 nd } \\
\hline 128 & $20.01 \mathrm{a}$ & $7.14 \mathrm{~b}$ & $14.57 \mathrm{ab}$ & \multicolumn{2}{|l|}{$\overline{\mathrm{y}}=16.24^{\mathrm{ns}}$} \\
\hline $\mathrm{CV}$ & \multicolumn{3}{|c|}{$33.88 \%$} & & \\
\hline \multirow{3}{*}{$\begin{array}{c}\text { Days after } \\
\text { sowing }\end{array}$} & \multicolumn{3}{|c|}{ Sowing periods } & \multirow{2}{*}{\multicolumn{2}{|c|}{ Adjusted equations }} \\
\hline & May 12th & June 23 rd & July 22nd & & \\
\hline & \multicolumn{3}{|c|}{-------- Yield $\left(\right.$ t.ha $\left.^{-1}\right)$-------- } & \multicolumn{2}{|l|}{ May 12th } \\
\hline 100 & $5.32 \mathrm{a}$ & $0.86 \mathrm{~b}$ & $1.66 \mathrm{~b}$ & \multirow{2}{*}{\multicolumn{2}{|c|}{$\begin{array}{r}\mathrm{Y}=9.181 .2-1.923 .1 * * \mathrm{x} \\
\text { June } 23 \mathrm{rd}\end{array}$}} \\
\hline 107 & $9.80 \mathrm{a}$ & $1.89 \mathrm{~b}$ & $1.50 \mathrm{~b}$ & & \\
\hline 114 & $5.31 \mathrm{a}$ & $1.59 \mathrm{~b}$ & $1.44 \mathrm{~b}$ & \multicolumn{2}{|l|}{$\overline{\mathrm{y}}=1.50^{\mathrm{ns}}$} \\
\hline 121 & $4.99 \mathrm{a}$ & $2.30 \mathrm{~b}$ & $2.19 \mathrm{~b}$ & \multicolumn{2}{|l|}{ July 22nd } \\
\hline 128 & $3.40 \mathrm{a}$ & $0.87 \mathrm{~b}$ & $1.49 \mathrm{~b}$ & \multicolumn{2}{|l|}{$\overline{\mathrm{y}}=1.66^{\mathrm{ns}}$} \\
\hline $\mathrm{VC}$ & \multicolumn{3}{|c|}{$35.01 \%$} & \\
\hline \multicolumn{2}{|c|}{ Sowing periods } & May 12th & & \multicolumn{2}{|c|}{ June 23rd $\quad$ July 22nd } \\
\hline \multicolumn{2}{|c|}{ Plants $/ \mathrm{m}^{-1}$ in the harvest } & $8.5(2.92) \mathrm{a}$ & & $6.1(2.46) \mathrm{b}$ & $1(2.25) \mathrm{c}$ \\
\hline \multicolumn{2}{|c|}{ Plant density } & $170,000 \mathrm{ha}^{-1}(85 \%)$ & & $122,000 \mathrm{ha}^{-1}(61 \%)$ & $00 \mathrm{ha}^{-1}(51 \%)$ \\
\hline \multicolumn{2}{|c|}{$\mathrm{CV}$} & & & \multicolumn{2}{|l|}{$5.09 \%$} \\
\hline
\end{tabular}

Averages followed by the same letter on the lines do not differ from each other by Tukey's test $(\mathrm{p}<0.05)$.

**; * Significant at 1 and 5\%, respectively, by the t-test. ns - not significant. Data transformed by .

Table 3. Moisture content, dry matter and 1,000-seed weight chickpea in different periods of sowing and harvesting.

\begin{tabular}{|c|c|c|c|c|}
\hline \multirow{2}{*}{$\begin{array}{c}\text { Days after } \\
\text { sowing }\end{array}$} & \multicolumn{3}{|c|}{ Sowing periods } & \multirow{2}{*}{ Adjusted equations } \\
\hline & May 12th & June 23rd & July 22nd & \\
\hline & \multicolumn{3}{|c|}{-------- Moisture content (\%) -------- } & May 12th \\
\hline 100 & $60.78 \mathrm{a}$ & $17.39 \mathrm{c}$ & $30.08 \mathrm{~b}$ & $\hat{\mathrm{Y}}=64.7-4.4^{* *} \mathrm{x}+0.08^{* *} \mathrm{x} \quad \mathrm{R}^{2}=0.84$ \\
\hline 107 & $48.39 \mathrm{a}$ & $8.22 \mathrm{~b}$ & $12.16 \mathrm{~b}$ & June $23 \mathrm{rd}$ \\
\hline 114 & $10.70 \mathrm{a}$ & $8.24 \mathrm{a}$ & $9.12 \mathrm{a}$ & $\hat{\mathrm{Y}}=16.6-1.1 * * \mathrm{x}+0.03 * * \mathrm{x}^{2} \quad \mathrm{R}^{2}=0.90$ \\
\hline 121 & $8.25 \mathrm{a}$ & $7.36 \mathrm{a}$ & $6.66 \mathrm{a}$ & July 22nd \\
\hline 128 & $5.97 \mathrm{~b}$ & $9.67 \mathrm{ab}$ & $12.40 \mathrm{a}$ & $\hat{\mathrm{Y}}=29.1-2.54 * * \mathrm{x}+0.07 * * \mathrm{x}^{2} \mathrm{R}^{2}=0.97$ \\
\hline $\mathrm{CV}$ & & $14.04 \%$ & & \\
\hline \multirow{3}{*}{$\begin{array}{c}\text { Days after } \\
\text { sowing }\end{array}$} & \multicolumn{3}{|c|}{ Sowing periods } & \multirow{2}{*}{ Adjusted equations } \\
\hline & May 12th & June 23rd & July 22nd & \\
\hline & \multicolumn{3}{|c|}{----- Seed dry matter (g) ----- } & May 12th \\
\hline 100 & $5.53 \mathrm{~b}$ & $7.08 \mathrm{a}$ & $6.38 \mathrm{ab}$ & $\hat{\mathrm{Y}}=-73.35+1.38 \mathrm{x}-0.006^{* *} \mathrm{x}^{2}$ \\
\hline 107 & $6.16 \mathrm{a}$ & $7.29 \mathrm{a}$ & $7.25 \mathrm{a}$ & $\underline{\text { June } 23 \mathrm{rd}}$ \\
\hline 114 & $7.63 \mathrm{a}$ & $7.46 \mathrm{a}$ & $7.14 \mathrm{a}$ & $\mathrm{Y}=-154.84+2.97 * * \mathrm{x}-0.014 * * \mathrm{x}^{2} \quad \mathrm{R}^{2}=0.87$ \\
\hline 121 & $6.46 \mathrm{a}$ & $7.36 \mathrm{a}$ & $6.16 \mathrm{a}$ & $\underline{\text { July } 22 \mathrm{nd}}$ \\
\hline 128 & $6.37 \mathrm{a}$ & $3.06 \mathrm{~b}$ & $6.68 \mathrm{a}$ & $\overline{\mathrm{y}}=6.72^{\mathrm{ns}}$ \\
\hline $\mathrm{CV}$ & & $11.63 \%$ & & \\
\hline \multirow{3}{*}{$\begin{array}{c}\text { Days after } \\
\text { sowing }\end{array}$} & \multicolumn{3}{|c|}{ Sowing periods } & \multirow{2}{*}{ Adjusted equations } \\
\hline & May 12th & June 23rd & July 22nd & \\
\hline & \multicolumn{3}{|c|}{------- 1,000-seed weight (g) -------- } & May 12th \\
\hline 100 & $345.97 \mathrm{a}$ & $215.50 \mathrm{c}$ & $239.52 \mathrm{~b}$ & 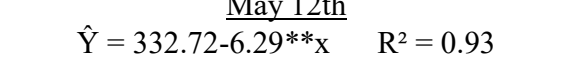 \\
\hline 107 & $293.51 \mathrm{a}$ & $197.68 \mathrm{~b}$ & $207.94 \mathrm{~b}$ & June 23rd \\
\hline 114 & $213.71 \mathrm{a}$ & $199.46 \mathrm{ab}$ & $195.48 \mathrm{~b}$ & $\mathrm{Y}=204.90^{\mathrm{ns}}$ \\
\hline 121 & $195.37 \mathrm{ab}$ & $204.11 \mathrm{a}$ & $187.90 \mathrm{~b}$ & July 22nd \\
\hline 128 & $175.03 \mathrm{~b}$ & $207.78 \mathrm{a}$ & $194.84 \mathrm{a}$ & $\hat{\mathrm{Y}}=235.51-5.24 \mathrm{x}+0.14 * * \mathrm{x}^{2}$ \\
\hline $\mathrm{CV}$ & & $3.89 \%$ & & \\
\hline
\end{tabular}

Averages followed by the same letter on the lines do not differ from each other by Tukey's test $(\mathrm{p}<0.05)$.

**; * Significant at 1 and $5 \%$, respectively, by the t-test. ns - not significant. Transformed data by arc sine . 
happen in this situation, according to Nascimento et al. (2016). This contributed to the reduction in seed number and also in production, for all sowing periods, at the end of the cycle. The increase in seed moisture content at 128 DAS, in both the June 23rd and July 22nd sowing, was due to climatic factors, such as rainfall and high relative air humidity.

The dry matter of seeds reached its maximum at 114 DAS, and did not differ at this stage, compared to the sowing periods. The May 12th sowing resulted in seeds with a dry matter of up to $7.63 \mathrm{~g} / 25$ seeds. The dry matter reduced and, at 128 DAS, it was $6.37 \mathrm{~g}$. In the June 23 rd sowing, a maximum of $7.46 \mathrm{~g} / 25$ seeds was reached at $114 \mathrm{DAS}$, decreasing to $3.06 \mathrm{~g}$ at $128 \mathrm{DAS}$. In the July 22nd sowing, the dry matter of seeds did not differ and it was, on an average, $6.72 \mathrm{~g} / 25$ seeds. Dry matter is an important characteristic for seed quality, since the ones with higher accumulation can generate more vigorous seedlings in the initial development period (Perin et al., 2002 cited by Araújo et al., 2015).

The cycle of BRS Aleppo chickpea cultivar is around 120 days (Nascimento et al., 2014). Considering the maturation stage at $121 \mathrm{DAS}$, which is the closest to this period, the dry matter of the seeds started to reduce, starting the deterioration process when it was still in the production field.

The largest variation in the size of chickpea seeds after their complete formation was only in length (Table 4). Pods from the plants of the May 12th sowing changed in length according to the size of seeds, over the harvesting period; this did not occur with width and thickness. The increase was linearly growing, with $22.76 \mathrm{~mm}$, on an average, at 128 DAS.

The biggest seeds or those with the highest density are normally the ones having well-formed embryos and with higher amounts of supplies; potentially, they are the most vigorous (Carvalho and Nakagawa, 2012).

The length of the seeds from the May 12th sowing was linearly decreasing, from $10.70 \mathrm{~mm}$ at 100 DAS to 8.43 $\mathrm{mm}$ at $128 \mathrm{DAS}$. For the June planting, seed length did not change, and it was, on an average, $9.16 \mathrm{~mm}$. The July 22nd sowing resulted in a shorter initial seed length, averaging 8.15 $\mathrm{mm}$, between the sowing periods. There was an increase up to 114 DAS $(9.06 \mathrm{~mm})$ and at the end of the cycle, it reduced to $8.69 \mathrm{~mm}$. The width and thickness of the seeds did not change much during the harvest season. There was a statistical difference only at 100 and 107 DAS, when the pods and seeds of the May planting had the largest sizes (Table 4). The May sowing resulted in a decrease over the harvest season. In the other sowing periods, there was no statistical difference, and the same occurred for seed thickness.

The width of pods did not differ during the harvesting seasons. As for the sowing periods described in Table 4, it was higher in July, with an average of $10.98 \mathrm{~mm}$, and lower in May $(10.48 \mathrm{~mm})$. The BRS Aleppo cultivar is desirable for the food industry and also for in natura consumption, since seed size ranges from 8 to $9.5 \mathrm{~mm}$ (Nascimento et al., 2016). Thus, harvests performed with a seed moisture that was suitable for storage resulted in a size (length) that was close to the culture average.

For all sowing periods, harvesting at 114 DAS resulted in seeds with a high germination power - $95 \%$ germination, on an average (Table 5). After this period, there was a reduction in seed germination for all sowing periods. However, a drastic reduction in seed germination was observed for the July 22nd sowing, which at 128 DAS resulted in only $49 \%$ of normal seedlings.

The germination rate index (GRI) for the May 12th sowing was 16.38 at 114 DAS (Table 5). For the July 22nd sowing, the maximum rate was found at 107 DAS (12.58). On the other hand, for the June 23rd sowing, when irrigation was suspended (at 100 DAS), seeds had already reached their maximum GRI and it did not change until 128 DAS, with 13.55 on an average.

The length of the primary root (Table 5), for the May sowing, reached $120 \mathrm{~mm}$ (121 DAS), for the June sowing, $136 \mathrm{~mm}$ (128 DAS), and for July, $125 \mathrm{~mm}$ (114 DAS). The length of the shoot, for the May 12th sowing reached 39 $\mathrm{mm}$, for the June $23 \mathrm{rd}$ sowing, $37 \mathrm{~mm}$, and for the July $22 \mathrm{nd}$ sowing, $42 \mathrm{~mm}$.

The dry matter of the seedlings, for the May 12th sowing, reached $0.0261 \mathrm{~g} /$ seedling at $128 \mathrm{DAS}$; for the June $23 \mathrm{rd}$ sowing, an average of $0.0318 \mathrm{~g} /$ seedlings and for the July 22nd sowing, $0.0317 \mathrm{~g} /$ seedling at 114 DAS.

According to the quality identity standards for seed production and commercialization in Brazil, a minimum of $80 \%$ of germination is required for $\mathrm{C} 1$ chickpea seedlings (Brasil, 2012). Therefore, in this study, seeds presented a high germination power. For the July 22nd sowing, the seeds harvested at 128 DAS had their germination compromised by the occurrence of rainfall near the harvest.

Hoskem et al. (2017), while evaluating the production and quality of Cícero chickpea seeds in the municipality of Montes Claros and São Norberto - Minas Gerais state, at different planting periods, found the maximum germination in seeds from the May 22nd sowing, with an average of $85.5 \%$. Araújo et al. (2010), comparing chickpea seed lots from different genotypes grown in the North of Minas Gerais, found their germination ranging from 33 to $73 \%$, and also remarkable vigor differences. Almeida et al. (1997), while testing stored seed lots from the IAC-Marrocos cultivar, found 59 to $87 \%$ of germination. The authors reported a marked decline in germination and vigor after the storage process. The same 
Table 4. Length of pods and seeds, width of pods and seeds, and thickness of chickpea seeds in different periods of sowing and harvesting.

\begin{tabular}{|c|c|c|c|c|}
\hline \multirow{2}{*}{$\begin{array}{c}\text { Days after } \\
\text { sowing }\end{array}$} & \multicolumn{3}{|c|}{ Sowing periods } & \multirow{2}{*}{ Adjusted equations } \\
\hline & May 12th & June 23rd & July 22nd & \\
\hline & \multicolumn{3}{|c|}{----- Pod lenght (mm) ---- } & May 12th \\
\hline 100 & $20.74 \mathrm{~b}$ & $22.09 \mathrm{a}$ & $20.44 \mathrm{~b}$ & $\hat{\mathrm{Y}}=20.71+0.080^{* *} \mathrm{x} \quad \mathrm{R}^{2}=0.96$ \\
\hline 107 & $21.16 \mathrm{~b}$ & $23.00 \mathrm{a}$ & $21.61 \mathrm{~b}$ & June 23 rd \\
\hline 114 & $21.80 \mathrm{a}$ & $21.20 \mathrm{a}$ & $21.16 \mathrm{a}$ & $\bar{y}=21.90^{\mathrm{ns}}$ \\
\hline 121 & $22.69 \mathrm{a}$ & $21.73 \mathrm{~b}$ & $21.00 \mathrm{~b}$ & July 22nd \\
\hline 128 & $22.76 \mathrm{a}$ & $21.46 \mathrm{~b}$ & $21.67 \mathrm{~b}$ & $\bar{y}=21.18^{\mathrm{ns}}$ \\
\hline $\mathrm{CV}$ & \multicolumn{3}{|c|}{$2.34 \%$} & \\
\hline \multirow{2}{*}{$\begin{array}{c}\text { Days after } \\
\text { sowing }\end{array}$} & \multicolumn{3}{|c|}{ Sowing periods } & \multirow{2}{*}{ Adjusted equations } \\
\hline & May 12th & June 23rd & July 22nd & \\
\hline & \multicolumn{3}{|c|}{---- Seed length $(\mathrm{mm})$---- } & May 12th \\
\hline 100 & $10.70 \mathrm{a}$ & $9.17 \mathrm{~b}$ & $8.15 \mathrm{c}$ & $\hat{\mathrm{Y}}=10.41-0.54 * * \mathrm{x} \quad \mathrm{R}^{2}=0.92$ \\
\hline 107 & $9.65 \mathrm{a}$ & $9.34 \mathrm{a}$ & $8.98 \mathrm{~b}$ & June $23 \mathrm{rd}$ \\
\hline 114 & $9.05 \mathrm{a}$ & $9.00 \mathrm{a}$ & $9.06 \mathrm{a}$ & $\overline{\mathrm{y}}=9.16^{\mathrm{ns}}$ \\
\hline 121 & $8.77 \mathrm{a}$ & $9.11 \mathrm{a}$ & $8.70 \mathrm{a}$ & July 22nd \\
\hline 128 & $8.43 \mathrm{~b}$ & $9.20 \mathrm{a}$ & $8.69 \mathrm{ab}$ & $\hat{\mathrm{Y}}=8.25+0.098 \times 0.0031 * \mathrm{x}^{2}$ \\
\hline $\mathrm{CV}$ & \multicolumn{3}{|c|}{$4.03 \%$} & \\
\hline \multirow{2}{*}{$\begin{array}{c}\text { Days after } \\
\text { sowing }\end{array}$} & \multicolumn{3}{|c|}{ Sowing periods } & \multirow{2}{*}{ Adjusted equations } \\
\hline & May 12th & June 23rd & July 22nd & \\
\hline & \multicolumn{3}{|c|}{------- Seed width $(\mathrm{mm})$------ } & May 12th \\
\hline 100 & $9.25 \mathrm{a}$ & $7.20 \mathrm{~b}$ & $6.86 \mathrm{~b}$ & $\mathrm{Y}=9.33-0.093^{* *} \mathrm{x} \quad \mathrm{R}^{2}=0.82$ \\
\hline 107 & $9.29 \mathrm{a}$ & $7.52 \mathrm{~b}$ & $7.33 \mathrm{~b}$ & $\underline{\text { June } 23 \mathrm{rd}}$ \\
\hline 114 & $7.33 \mathrm{a}$ & $7.33 \mathrm{a}$ & $7.37 \mathrm{a}$ & $\bar{y}=9.16^{\mathrm{ns}}$ \\
\hline 121 & $7.31 \mathrm{a}$ & $7.35 \mathrm{a}$ & $7.28 \mathrm{a}$ & July 22nd \\
\hline 128 & $6.99 \mathrm{a}$ & $7.27 \mathrm{a}$ & $7.14 \mathrm{a}$ & $\overline{\mathrm{y}}=7.20^{\mathrm{ns}}$ \\
\hline $\mathrm{CV}$ & & $4.92 \%$ & & \\
\hline Days after & & Sowing peri & & Adiusted egurtions \\
\hline sowing & May 12th & June 23rd & July 22nd & Adjusted equations \\
\hline & & Seed thickness & ---- & May 12 th \\
\hline 100 & $8.79 \mathrm{a}$ & $7.04 \mathrm{~b}$ & $6.70 \mathrm{~b}$ & $\mathrm{Y}=8.55-0.063^{* *} \mathrm{x} \quad \mathrm{R}^{2}=0.91$ \\
\hline 107 & $8.01 \mathrm{a}$ & $7.48 \mathrm{ab}$ & $7.20 \mathrm{~b}$ & $\underline{\text { June } 23 \mathrm{rd}}$ \\
\hline 114 & $7.37 \mathrm{a}$ & $7.23 \mathrm{a}$ & $7.18 \mathrm{a}$ & $\overline{\mathrm{y}}=7.24^{\mathrm{ns}}$ \\
\hline 121 & $7.20 \mathrm{a}$ & $7.24 \mathrm{a}$ & $7.29 \mathrm{a}$ & July 22nd \\
\hline 128 & $6.98 \mathrm{a}$ & $7.19 \mathrm{a}$ & $7.07 \mathrm{a}$ & $\bar{y}=7.09^{\mathrm{ns}}$ \\
\hline $\mathrm{CV}$ & & $4.29 \%$ & & \\
\hline Sowing & & May 12th & June 23rd & July 22nd \\
\hline Pod wid & & $10.48 \mathrm{c}$ & $10.64 \mathrm{~b}$ & $10.98 \mathrm{a}$ \\
\hline $\mathrm{C}$ & & & & \\
\hline
\end{tabular}

Averages followed by the same letter on the lines do not differ from each other by Tukey's test $(p<0.05)$.

**; * Significant at 1 and $5 \%$, respectively, by the t-test. ns - not significant.

occurred with soybean seeds, with delays in harvesting and after storage, according to Zuffo et al., 2017.

The production of high quality seeds depends on several factors, since their formation. At temperatures considered high for chickpea cultivation, above $30^{\circ} \mathrm{C}$, as occurred from September to November in the region, the reproductive period is accelerated. Moreover, rainfall during the harvest season compromises the physiological quality of seeds; this occurred in the June and July sowing, starting from 121 DAS. 
Table 5. Germination, germination rate index (GRI), shoot length and primary root length, and dry matter of chickpea seedlings at the end of the germination test, in different sowing and harvesting periods.

\begin{tabular}{|c|c|c|c|c|c|}
\hline \multirow{2}{*}{$\begin{array}{l}\text { Days after } \\
\text { sowing }\end{array}$} & \multicolumn{3}{|c|}{ Sowing periods } & \multirow{2}{*}{\multicolumn{2}{|c|}{ Adjusted equations }} \\
\hline & May 12th & June 23rd & July 22nd & & \\
\hline & \multicolumn{3}{|c|}{----------- Germination (\%) ---------- } & \multicolumn{2}{|l|}{ May 12th } \\
\hline 100 & $30(0.58) b$ & $79(1.10) b$ & $92(1.30) \mathrm{a}$ & $\hat{\mathrm{Y}}=36.31+6.94 \mathrm{x}-0.19 * * \mathrm{x}^{2}$ & $\mathrm{R}^{2}=0.86$ \\
\hline 107 & $88(1.24) \mathrm{ab}$ & $94(1.36) \mathrm{a}$ & $80(1.11) b$ & June 23rd & \\
\hline 114 & $98(1.47) \mathrm{a}$ & $96(1.40) \mathrm{a}$ & $92(1.33) \mathrm{a}$ & $\mathrm{Y}=86.51+1.47 \mathrm{x}-0.095 * * \mathrm{x}^{2}$ & $\mathrm{R}^{2}=0.79$ \\
\hline 121 & $86(1.19) \mathrm{a}$ & $92(1.29) \mathrm{a}$ & $83(1.15) \mathrm{a}$ & July 22nd & \\
\hline 128 & $91(1.31) \mathrm{a}$ & $90(1.26) \mathrm{a}$ & $49(0.78) b$ & $\hat{\mathrm{Y}}=80.49+1.92 \mathrm{x}-0.058 * * \mathrm{x}^{2}$ & $\mathrm{R}^{2}=0.87$ \\
\hline $\mathrm{CV}$ & \multicolumn{3}{|c|}{$9.87 \%$} & & \\
\hline \multirow{2}{*}{$\begin{array}{l}\text { Days after } \\
\text { sowing }\end{array}$} & \multicolumn{3}{|c|}{ Sowing periods } & \multirow{2}{*}{\multicolumn{2}{|c|}{ Adjusted equations }} \\
\hline & May 12th & June 23rd & July 22nd & & \\
\hline & \multicolumn{3}{|c|}{------------------- GRI --------------------- } & \multicolumn{2}{|l|}{ May 12th } \\
\hline 100 & $9.11 \mathrm{~b}$ & $13.29 \mathrm{a}$ & $12.71 \mathrm{a}$ & $\hat{\mathrm{Y}}=7.60+1.05 * * x-0.035^{* *} \mathrm{x}^{2}$ & $\mathrm{R}^{2}=0.68$ \\
\hline 107 & $9.92 \mathrm{~b}$ & $12.88 \mathrm{a}$ & $12.58 \mathrm{a}$ & June 23rd & \\
\hline 114 & $16.38 \mathrm{a}$ & $14.21 \mathrm{~b}$ & $11.88 \mathrm{c}$ & $\overline{\mathrm{y}=13.55^{\mathrm{ns}}}$ & \\
\hline 121 & $16.38 \mathrm{a}$ & $13.54 \mathrm{~b}$ & $12.08 \mathrm{~b}$ & July 22nd & \\
\hline 128 & $8.38 \mathrm{~b}$ & $13.83 \mathrm{a}$ & $8.96 \mathrm{~b}$ & $\hat{\mathrm{Y}}=12.52+0.093 * * \mathrm{x}-0.0074 * * \mathrm{x}^{2}$ & $\mathrm{R}^{2}=0.87$ \\
\hline $\mathrm{CV}$ & & $8.04 \%$ & & & \\
\hline \multirow{2}{*}{$\begin{array}{l}\text { Days after } \\
\text { sowing }\end{array}$} & \multicolumn{3}{|c|}{ Sowing periods } & \multirow{2}{*}{\multicolumn{2}{|c|}{ Adjusted equations }} \\
\hline & May 12th & June 23rd & July 22nd & & \\
\hline & \multicolumn{3}{|c|}{ - Primary root length $(\mathrm{mm})--$} & \multicolumn{2}{|l|}{ May 12 th } \\
\hline 100 & $87.90 \mathrm{ab}$ & $84.21 \mathrm{~b}$ & $100.14 \mathrm{a}$ & $\hat{\mathrm{Y}}=88.16+2.43 \mathrm{x}-0.084^{* *} \mathrm{x}^{2}$ & $\mathrm{R}^{2}=0.24$ \\
\hline 107 & $107.84 \mathrm{a}$ & $111.18 \mathrm{a}$ & $102.5 \mathrm{a}$ & $\underline{\text { June } 23 \mathrm{rd}}$ & \\
\hline 114 & $86.92 \mathrm{~b}$ & $135.62 \mathrm{a}$ & $125.12 \mathrm{a}$ & $\hat{\mathrm{Y}}=88.09+3.36 \mathrm{x}-0.07 * * \mathrm{x}^{2}$ & $\mathrm{R}^{2}=0.59$ \\
\hline 121 & $120.37 \mathrm{a}$ & $105.90 \mathrm{a}$ & $76.80 \mathrm{~b}$ & July 22nd & \\
\hline 128 & $84.25 \mathrm{~b}$ & $136.06 \mathrm{a}$ & $71.66 \mathrm{~b}$ & $\hat{\mathrm{Y}}=99.46+2.32 \mathrm{x}-0.13 * * \mathrm{x}^{2}$ & $\mathrm{R}^{2}=0.65$ \\
\hline $\mathrm{CV}$ & \multicolumn{3}{|c|}{$8.83 \%$} & & \\
\hline \multirow{2}{*}{$\begin{array}{l}\text { Days after } \\
\text { sowing }\end{array}$} & \multicolumn{3}{|c|}{ Sowing periods } & \multirow{2}{*}{\multicolumn{2}{|c|}{ Adjusted equations }} \\
\hline & May 12th & June 23rd & July 22nd & & \\
\hline & \multicolumn{3}{|c|}{-- Shoot length (mm) -- } & \multirow{2}{*}{\multicolumn{2}{|c|}{$\hat{\mathrm{Y}}=24.63+1.85 \mathrm{x}-0.064 * * \mathrm{x}^{2} \quad \mathrm{R}^{2}=0.78$}} \\
\hline 100 & $26.72 \mathrm{~b}$ & $40.25 \mathrm{a}$ & $43.26 \mathrm{a}$ & & \\
\hline 107 & $29.94 \mathrm{~b}$ & $37.13 \mathrm{ab}$ & $41.25 \mathrm{a}$ & \multicolumn{2}{|c|}{$\underline{\text { June } 23 \mathrm{rd}}$} \\
\hline 114 & $39.25 \mathrm{a}$ & $35.50 \mathrm{a}$ & $42.40 \mathrm{a}$ & \multicolumn{2}{|l|}{$\bar{y}=37.64^{\mathrm{ns}}$} \\
\hline 121 & $38.49 \mathrm{a}$ & $36.97 \mathrm{a}$ & $21.68 \mathrm{~b}$ & July 22nd & \\
\hline 128 & $24.91 \mathrm{~b}$ & $38.37 \mathrm{a}$ & $26.22 \mathrm{~b}$ & $\hat{\mathrm{Y}}=45.69-0.77 * *_{x}$ & $=0.69$ \\
\hline $\mathrm{CV}$ & & $14.87 \%$ & & & \\
\hline Days after & & wing periods & & Adiucted ecuntions & \\
\hline sowing & May 12th & June 23rd & July 22nd & Adjusted equations & \\
\hline & ---- & g dry matter & - = & May 12th & \\
\hline 100 & $0.0288 \mathrm{~b}$ & $0.0349 \mathrm{a}$ & $0.0298 \mathrm{~b}$ & $\hat{\mathrm{Y}}=0.027-0.00096 \mathrm{x+0.0000} 3 * * \mathrm{x}^{2}$ & ${ }^{2} \mathrm{R}^{2}=0.67$ \\
\hline 107 & $0.0193 \mathrm{~b}$ & $0.0272 \mathrm{a}$ & $0.0208 \mathrm{~b}$ & $\underline{\text { June } 23 \mathrm{rd}}$ & \\
\hline 114 & $0.0208 \mathrm{c}$ & $0.0378 \mathrm{a}$ & $0.0317 \mathrm{~b}$ & $\mathrm{y}=0.0318^{\mathrm{ns}}$ & \\
\hline 121 & $0.0250 \mathrm{~b}$ & $0.0332 \mathrm{a}$ & $0.0266 \mathrm{~b}$ & July 22nd & \\
\hline 128 & $0.0261 \mathrm{a}$ & $0.0261 \mathrm{a}$ & $0.0142 \mathrm{~b}$ & $\hat{\mathrm{Y}}=0.026+0.0006^{* *} \mathrm{x}-0.00003^{* *} \mathrm{x}$ & $\mathrm{R}^{2}=0.50$ \\
\hline $\mathrm{CV}$ & & $8.74 \%$ & & & \\
\hline
\end{tabular}

Averages followed by the same letter on the lines do not differ from each other by Tukey's test $(p<0.05)$.

**; * Significant at 1 and $5 \%$, respectively, by the t-test. ns - not significant. 


\section{Conclusions}

The best sowing period for the production and quality of chickpea seeds was May, and the harvest was carried out close to 114 days after sowing, considering the suspension of the irrigation at 100 days. With a delay in planting, there is a risk of rainfall during the harvest season, which could compromise the quality of seeds.

\section{Acknowledgments}

The authors thank the FAPEMIG (Fundação de Amparo à Pesquisa de Minas Gerais) for its financial support during this study.

\section{References}

ALMEIDA, L.D.; BRAGA, N.R.; SANTOS, R.R.; GALLO, P.B.; PEREIRA, J.C.V.N.A. Comportamento de sementes de grão-de-bico na armazenagem. Bragantia, v.56, n.1, p.97-102, 1997. http://www.scielo. br/scielo.php?script=sci_arttext\&pid=S0006-87051997000100011

ARAÚJO, A.V.D.; FERREIRA, I.C.P.V.; BRANDÃO JUNIOR, D.S.; BRANDÃO, A.A.; AQUINO, C.F.; COSTA, C.A. Quality of the seeds of different genotypes of chickpea produced in the North of Minas Gerais. Ciência Rural, v.40, n.5, p.1031-1036, 2010. http://www.scielo. br/scielo.php?script $=$ sci_arttext\&pid=S0103-84782010000500005

ARTIGA, O.P.; SPEHAR, C.R.; BOITEUX, L.S.; NASCIMENTO, W.M. Avaliação de genótipos de grão de bico em cultivo de sequeiro nas condições de cerrado. Brazilian Journal of Agricultural Sciences (Agrária), v.10, n.1, p.102-109, 2015. http://www.agraria.pro.br/ sistema/index.php?journal $=$ agraria \&page $=$ article $\&$ op $=$ viewArticle\&path $\% 5 \mathrm{~B} \% 5 \mathrm{D}=$ agraria_v10i1a5129

BRASIL. Sistema de Consulta à Legislação - SISLEGIS. Ministério da Agricultura, Pecuária eAbastecimento. Secretaria de DefesaAgropecuária. PORTARIA No 111, set. 2012. http://sistemasweb.agricultura.gov.br/ sislegis/action/detalhaAto.do?method=consultarLegislacaoFederal

BRASIL. Ministério da Agricultura, Pecuária e Abastecimento. Regras para análise de sementes. Ministério da Agricultura, Pecuária e Abastecimento. Secretaria de Defesa Agropecuária. Brasília, DF: MAPA/ACS, 2009. 395p. http://www.agricultura.gov.br/arq editor/ file/2946_regras_analise_sementes.pdf.

CARVALHO, N.M.; NAKAGAWA, J. Sementes: Ciência, tecnologia e produção. 5.ed. Jaboticabal: FUNEP, 2012. 590p.

HOSKEM, B.C.S.; COSTA, C.A.; NASCIMENTO, W.M.; SANTOS, L.D.T.; MENDES, R.B.; MENEZES, J.B.C. Productivity and quality of chickpea seeds in Northern Minas Gerais, Brazil. Brazilian Journal of Agricultural Sciences (Agrária), v.12, n.3, p.261-263, 2017. http://agraria.pro.br/ojs-2.4.6/index.php?journal=agraria\&page $=$ article $\&$ op $=$ view $\&$ path $\% 5 \mathrm{~B} \% 5 \mathrm{D}=$ agraria_v $12 \mathrm{i} 3 \mathrm{a} 5445$
INMET. Instituto Nacional de Meteorologia. BDMEP: Banco de dados meteorológicos para ensino e pesquisa. Disponível em: http:// www.inmet.gov.br/portal/index. php?r=bdmep/bdmep Accessed on jul $4^{\text {th }}, 2015$.

MARCOS-FILHO, J. Fisiologia de sementes de plantas cultivadas. Piracicaba: FEALQ, 2005. 495p.

MAGUIRE, J.D. Speed of germination-aid in selection and evaluation for seedling emergence and vigor. Crop Science, v.2, n.2, p.176-177, 1962. https://dl.sciencesocieties.org/publications/cs/ abstracts/2/2/CS0020020176/

MAROUELLI, W.A.; SILVA, H.R.; SILVA, W.L.C. Procedimento simplificado para o manejo de água em hortaliças irrigadas por aspersão. Brasília, DF: Embrapa Hortaliças, 2010. p.1-9.

NASCIMENTO, W.M.; SILVA, P.P.; ARTIAGA, O.P.; SUINAGA, F.A. Grão-de-bico. In: NASCIMENTO, W.M. Hortaliças Leguminosas. Brasília: Embrapa Hortaliças, 2016. p.89-118.

NASCIMENTO, W.M.; ARTIAGA, O.P.; BOITEUX, L.S.; SUINAGA, F.A.; REIS, A.; PINHEIRO, J.B.; SPEHAR, C.R. BRS Aleppo: grão de bico. Maior tolerância a fungos de solo. Brasília; Anápolis: Embrapa Hortaliças, 2014. 2p.

NASCIMENTO, W.M.; PESSOA, H.B.S.V.; GIORDANO, L.B. Cultivo do grão-de-bico (Cicer arietinum L.). Brasília, DF: Embrapa-CNPH, 1998. 14p.

PERIN, A.; ARAÚJO, A.P.; TEIXEIRA, M.G. Efeito do tamanho da semente na acumulação de biomassa e nutrientes e na produtividade do feijoeiro. Pesquisa Agropecuária Brasileira, Brasília, v.37, n.12, p.1711-1718, 2002. http://www.alice.cnptia.embrapa.br/bitstream/ doc/108851/1/1711.pdf

PESSOA, H.B.S.V. Solos e adubação. In: NASCIMENTO, W.M.; PESSOA, H.B.S.V.; GIORDANO, L.B. (Ed.). Cultivo do grão-debico (Cicer arietinum L.). Brasília: EMBRAPA-CNPH, 1998. 4p. (EMBRAPA-CNPH. Instruções Técnicas da Embrapa Hortaliças, 14).

RAO, P.P.; BIRTHAL, P.S.; BHAGAVATULA, S.; BANTILAN, M.C.S. Chickpea and Pigeonpea Economies in Asia: Facts, Trends and Outlook. Andhra Pradesh, India: International Crops Research Institute for the Semi-Arid Tropics, 2010. p.1-76.

SILVA, W.L.C. Irrigação. In: NASCIMENTO, W.M.; PESSOA, H.B.S.V.; GIORDANO, L.B. (Ed.). Cultivo do grão-de-bico (Cicer arietinum L.). Brasília: EMBRAPA-CNPH, 1998. p.4-5. (EMBRAPACNPH. Instruções Técnicas da Embrapa Hortaliças, 14).

ZUFFO, A.M.; JÚNIOR, J.M.Z.; ZAMBIAZZI, E.V.; STEINER, F. Physiological and sanitary quality of soybean seeds harvested at different periods and submitted to storage. Pesquisa Agropecuária Tropical, v.47, n.3, p.312-320, Jul./Set. 2017. http://www.scielo.br/ $\mathrm{pdf} / \mathrm{pat} / \mathrm{v} 47 \mathrm{n3} / 1983-4063-$ pat-47-03-0312.pdf 